\title{
Conformational and Functional Properties of Soybean Proteins Produced by Extrusion-Hydrolysis Approach
}

\author{
Wenjun Ma, ${ }^{1}$ Baokun Qi, ${ }^{1}$ Rokayya Sami $\mathbb{D},{ }^{1,2}$ Lianzhou Jiang $\mathbb{D},{ }^{1}$ \\ Yang $\mathrm{Li}\left(\mathbb{B}^{1,},{ }^{1,3}\right.$ and Hui Wang ${ }^{4}$ \\ ${ }^{1}$ College of Food Science, Northeast Agricultural University, Harbin 150030, China \\ ${ }^{2}$ Department of Food Science and Nutrition, Taif University, Taif, Al-huwayah 888, Saudi Arabia \\ ${ }^{3}$ Harbin Institute of Food Industry, Harbin 150030, China \\ ${ }^{4}$ Center for Crops Utilization Research, Iowa State University, Ames, IA, USA
}

Correspondence should be addressed to Lianzhou Jiang; jlz_neau@163.com and Yang Li; liyang_neau@163.com

Received 18 February 2018; Revised 5 April 2018; Accepted 15 April 2018; Published 23 May 2018

Academic Editor: Barbara Bojko

Copyright (C) 2018 Wenjun Ma et al. This is an open access article distributed under the Creative Commons Attribution License, which permits unrestricted use, distribution, and reproduction in any medium, provided the original work is properly cited.

\begin{abstract}
The conformational and functional changes of soybean protein after a hybrid extrusion-hydrolysis method were evaluated. Three extrusion temperatures $\left(60,80\right.$, and $\left.100^{\circ} \mathrm{C}\right)$ were used prior to enzymatic hydrolysis. The hydrolysis degrees, molecular weight profiles, solubilities, surface hydrophobicities, sulphydryl contents, disulfide bound, water holding capacity, emulsion, and foam properties of the protein isolated from the enzyme-hydrolyzed extruded soybeans were analyzed. It shows that extrusion caused significant changes in the hydrophobicity, molecular weight distribution, solubility, surface hydrophobicity, emulsification activity, and stability of the protein. The increase of molecular weights could be attributed to the formation of protein aggregates during extrusion. Extrusion and enzymatic hydrolysis led to a sharp increase in the number of disulfide bonds with a decrease of the sulphydryl group. The water holding capacity and the solubility of protein increased with the increase of extrusion temperature and hydrolysis time. Extrusion improved the emulsifying activity but reduced the emulsifying stability of the recovered proteins. Extrusion improved the foam capacity but reduced the foam stability of the proteins. The data demonstrated that the extrusionhydrolysis treatment significantly altered the conformational and functional properties of soybean protein, which may be further optimized for the development of new soy protein ingredient with desired functional properties.
\end{abstract}

\section{Introduction}

Soybean is one of the most important oilseed kinds in the world. It is source of vegetable protein with high nutrition values [1] and versatile applications in food products at a reasonable cost [2]. The uses of soybean protein in food or nutraceutical products has been increasing steadily due to the health claim authorized by the Food and Drug Administration (FDA) in 1999 that " 25 grams of soy protein a day, as part of a diet low in saturated fat and cholesterol, may reduce the risk of heart disease."

Extrusion technique has been applied for soy foods processing recently, which is well known as a texturized soy protein-based meat analog [3, 4]. Extrusion can result in the disruption of compact quaternary and tertiary structures of soy protein and also can improve the efficiency of enzymatic hydrolysis [5]. Therefore, enzymatic hydrolysis is often applied after extrusion to modify the functional properties of soy protein. Clemente [6] reported that enzymatic hydrolysis can enhance or reduce the functional properties and nutritional value of soy protein. Chen et al. [7] found that extrusion increased the accessibility of soy protein to enzymatic hydrolysis and improved the emulsification properties of the protein. Lamsal et al. [8] evaluated the functional properties of the enzyme-hydrolyzed extruded soybean flour and demonstrated the extrusion process which affected the functional and sensory properties of soy protein. Furthermore, Surowka et al. [9] found that after extrusion, all the subunits of soybean protein were rapidly degraded by enzyme. Although there is 
abundant evidence that the extrusion and associated enzymatic hydrolysis could alter the structural and functional properties of soy protein, most of the previous extrusion studies used soy protein isolate power. There is a rare study in that field, dealing with the behaviors of soy protein isolated from extruded whole soybeans at different extrusion temperature, as well as the impact of consequent enzymatic hydrolysis on the extruded soy protein.

This study was designed to (1) investigate the effects of extrusion temperatures and associated enzymatic hydrolysis on the conformational changes of soy protein and (2) quantify the conformational and functional properties of the protein.

\section{Materials and Methods}

2.1. Materials. Full-fat soybean flakes (from soybean cultivar Dong-Nong 42, harvested in 2017 in Harbin, China) containing $20 \%$ fat and $40 \%$ crude protein on a dry basis were obtained from Lanshan Group (Shandong, China). The flakes were sealed and stored in plastic bags at $4^{\circ} \mathrm{C}$ until further use. Protex 6L (alkaline serine endopeptidase from Bacillus licheniformis, $580000 \mathrm{DU} / \mathrm{g}$ ) was purchased from Novozymes (Tianjin, China). Phthaldialdehyde (OPA), 5,5'-dithio-bis 2-nitrobenzoic acid (DTNB), 2-nitro-5-thiosulphobenzoate (NTSB) and 1-anilino-8-naphthalenesulphonate (ANS) were purchased from Sigma-Aldrich (St. Louis, MO, USA). All other reagents were of analytical grade.

\subsection{Extrusion Treatment. A corotating twin screw extruder} (Evolum 25, Clextral, Firminy, France) equipped with a feeder (model T20, K-TRON (Schweiz) AG, Hillenbrand, France) was used in all extrusion treatments. The screw has a length to diameter ratio of $32: 1$ and 11 sections of conveying and kneading screws. The extrusion conditions were as follows: feed rate: $50 \mathrm{~g} / \mathrm{min}$; 5-barrel temperatures sections were $30,30,40,40$, and $50^{\circ} \mathrm{C}$. Preliminary extrusion runs showed that full-fat soy flakes needed to contain $16 \%$ moisture for satisfactory extrusion. The moisture content of the extruder during extrusion was adjusted to $16 \%$ by adding water to full-fat soybean flakes directly. The soybean flakes were first ground into powder using a laboratory grinder (FW-100, Shaoxing Kehong Instrument Co., Ltd., Zhejiang, China) before passing through a 60 -mesh sieve $(<250 \mu \mathrm{m})$. The only change was the die temperatures, which was set at 60,80 , and $100^{\circ} \mathrm{C}$, respectively, for each treatment. The extruder was cooled to room temperature before grinding into fine powder $(<250 \mu \mathrm{m})$. The final soybean powder was stored in plastic bags at $4^{\circ} \mathrm{C}$ until subsequent enzymatic hydrolysis treatments.

2.3. Enzymatic Hydrolysis Treatment. Soybean flakes with and without extrusion were ground and subjected to pass through a 60-mesh sieve [10]. Afterwards, the flour was added to water to achieve solids-to-water ratio of $1: 6(\mathrm{w} / \mathrm{v})$. The $\mathrm{pH}$ of the slurry was adjusted to 9 through the addition of $2 \mathrm{~N}$ $\mathrm{NaOH}$. The slurry was incubated at $50^{\circ} \mathrm{C}$ in a water bath. Protex $6 \mathrm{~L}$ was added to the slurry at a dosage of $1.85 \%$ (v/w, based on the dry weight of the soybean flour). A continuous stirring device was used to disperse the slurry during the incubation period. The hydrolysis duration was set to $0.5,1.0,1.5$, 2.0, 2.5, and $3.0 \mathrm{~h}$, respectively. Enzyme was then thermally deactivated. Finally, the slurry was centrifuged at $8,000 \times \mathrm{g}$ for $20 \mathrm{~min}$ at $20^{\circ} \mathrm{C}$ (model TGL-16G, Anting Scientific Instrument Factory, Shanghai, China). The aqueous phase was carefully collected for subsequent isolation of protein.

2.4. Protein Isolation. The isolation of protein from the aqueous phase was initiated by adjusting the $\mathrm{pH}$ of the aqueous phase to 4.5 using $0.2 \mathrm{M} \mathrm{HCl}$, in order to precipitate out the protein. The protein was subsequently collected by centrifugation at $10,000 \times \mathrm{g}, 4^{\circ} \mathrm{C}$ for $15 \mathrm{~min}$. The acid-precipitated protein was washed four times and neutralized using $\mathrm{NaOH}$ $(2.0 \mathrm{M})$. Afterwards, the protein-rich solution was subjected to freeze-drying in a freeze dryer (FEtseries, GOLD SIM, Newark, USA) to isolate the hydrolyzed soybean protein powder (HSPP). The crude protein of the HSPP ranged from $70 \%$ to $78 \%$, Nitrogen contents were converted to crude protein contents using a factor of 6.25 .

2.5. Hydrolysis Degree Determination. The degree of hydrolysis $(\mathrm{DH})$ is defined as the ratio of the number of peptide bonds hydrolyzed to the total number of peptide bonds per unit weight present in HSPP. The DH of each HSPP sample was determined using the modified OPA method [11]. The method was modified by adjusting $1.5 \mathrm{~mL}$ OPA reagents to $200 \mu \mathrm{L}$ of standard, blank andHSPP sample in individual tubes then left to react for $2 \mathrm{~min}$. The absorbance was recorded at $340 \mathrm{~nm}$ (Lengguang Technology Co., Ltd., Shanghai, China). The DH\% was calculated using

$$
\text { Serine } \begin{aligned}
\mathrm{NH}_{2}= & \frac{\mathrm{OD}_{\text {sample }}-\mathrm{OD}_{\text {blank }}}{\mathrm{OD}_{\text {standard }}-\mathrm{OD}_{\text {blank }}} \times 0.9516 \mathrm{meqv} / \mathrm{L} \\
& \times \frac{0.1 \times 100}{X \times P} \mathrm{~L} / \mathrm{g} \\
H= & \frac{\text { Serine } \mathrm{NH}_{2}-\beta}{\alpha} \\
\mathrm{DH}= & \frac{h}{h_{\text {tot }}} \times 100
\end{aligned}
$$

where $h=$ number of hydrolyzed bonds; $h_{\text {tot }}=$ total number of peptide bonds per protein equivalent ( 7.8 specific to soybean protein); $\beta=0.342$ (specific for soybean protein); $\alpha=0.970$ (specific for soybean protein); $\mathrm{OD}_{\text {sample }}=$ absorbance of sample at $340 \mathrm{~nm} ; \mathrm{OD}_{\text {blank }}=$ absorbance of water at $340 \mathrm{~nm}$; $\mathrm{OD}_{\text {standard }}=$ absorbance of 1 -serine at $340 \mathrm{~nm} ; X=$ amount of sample (g); and $P=$ protein (\%) in sample.

2.6. SDS-PAGE Analysis. Sodium dodecyl sulfate-polyacrylamide gel electrophoresis (SDS-PAGE) was carried out using the discontinuous system ( $15 \%$ separating/4\% stacking gel) $[12,13]$. Aliquots of each sample were mixed with $2 \mathrm{x}$ sample dissolving buffer (4\% SDS, $20 \%$ glycerol, $0.125 \mathrm{M}$ Tris- $\mathrm{HCl}$ buffer $\mathrm{pH}$ 6.8, $0.02 \%$ bromophenol blue). SDS-PAGE was carried out under reducing and nonreducing conditions. For reducing SDS-PAGE, $80 \mu \mathrm{L}$ of sample $(2 \mathrm{mg} / \mathrm{mL})$ was 
mixed with $20 \mu \mathrm{L}$ of $10 \%$ SDS, $2 \mu \mathrm{L}$ of 2 -mercaptoethanol mercaptoethanol and $1 \mu \mathrm{L}$ of $1 \% \mathrm{w} / \mathrm{v}$ bromophenol blue. For nonreducing SDS-PAGE, 2-mercaptoethanol was not added. The samples were heated at $100^{\circ} \mathrm{C}$ for $5 \mathrm{~min}$ and centrifuged at $15,000 \times \mathrm{g}$ for $10 \mathrm{~min}$ at room temperature. The supernatant was collected and loaded onto SDS-PAGE gels. The electrophoresis experiments ran at $80 \mathrm{~V}$ and subsequently ran at $120 \mathrm{~V}$ until the dye reached the bottom of the gel. After electrophoresis, the gel was stained with $0.05 \%(\mathrm{w} / \mathrm{v})$ Coomassie blue R250 in 15\% (v/v) methanol and 5\% (v/v) acetic acid and destained with $30 \%(\mathrm{v} / \mathrm{v})$ methanol and $10 \%$ (v/v) acetic acid. High molecular weight markers (Solarbio Co., Ltd., Beijing, China) were used to estimate the molecular weight of proteins.

2.7. High-Performance Size Exclusion Chromatogram. Highperformance size exclusion chromatography (HPSEC) was carried out according to the method [14]. All samples were dissolved in water to a concentration of $1 \mathrm{mg} / \mathrm{mL}$ and then centrifuged at $10,000 \times \mathrm{g}\left(25^{\circ} \mathrm{C}\right)$ for $10 \mathrm{~min}$. The supernatant was filtered through a cellulose acetate membrane with a pore size of $0.22 \mu \mathrm{m}$. The resulting solution was injected into the ÄKTA purifier system equipped with a Superdex ${ }^{\mathrm{TM}}$ $7510 / 300 \mathrm{GL}$. The mobile phase consisted of $50 \mathrm{mM}$ of phosphate buffer and $300 \mathrm{mM}$ of $\mathrm{NaCl}$. Data collection was performed at $214 \mathrm{~nm}$ using Unicorn Software (Version 5.01). Peak molecular weight ranges were estimated based on the calibration curve from a series of protein standards (thyroglobulin, bovine-globulin, chicken ovalbumin, equine myoglobin and vitamin $B_{12}$ ).

2.8. Sulphydryl and Disulphide Bond Contents. HSPP at $15 \mathrm{mg}$ were dissolved in $5 \mathrm{~mL}$ pH 8.0 buffer $(0.086 \mathrm{M}$ Tris, $0.09 \mathrm{M}$ glycine, and $0.04 \mathrm{M} \mathrm{Na} \mathrm{NDDTA}_{2}$ with (total sulphydryl) or without $8 \mathrm{M}$ urea (exposed sulphydryl) [15]. After that, $50 \mu \mathrm{L}$ of Ellman's reagent ( $4 \mathrm{mg} \mathrm{DTNB} / \mathrm{mL}$ buffer) were added. The resultant slurry was incubated at $25^{\circ} \mathrm{C}$ for $1 \mathrm{~h}$, prior to centrifugation at $5000 \times \mathrm{g}$ for $15 \mathrm{~min}$ (model TGL-16G, Anting Scientific Instrument Factory, Shanghai, China). The absorbance of the supernatant was measured at $412 \mathrm{~nm}$ (SHJH Co. Ltd., Shanghai, China) using the Tris-Gly buffer containing Ellman's reagent as the blank. Sulphydryl groups were determined using

$$
\mu \mathrm{mol} \mathrm{SH} / \mathrm{g}=\frac{73.53 \times A_{412} \times D}{C},
$$

where $A_{412}$ is the absorbance at $412 \mathrm{~nm}, D$ is the dilution factor, $C$ is the sample concentration $(\mathrm{mg} / \mathrm{mL})$, and. 53 is derived from $10^{6} /\left(1.36 \times 10^{4}\right)$, and $1.36 \times 10^{4}$ is the molar absorptivity.

Freshly prepared NTSB assay solution $(3 \mathrm{~mL})$ was added to $2 \mathrm{~mL}$ of HSPP solution, and then the mixture was incubated in the dark at room temperature for $25 \mathrm{~min}$. After the reaction, the absorbance of the solution was measured at $412 \mathrm{~nm}$ using the test NTSB solution as the reference. The total disulphide content was calculated using a molar extinction coefficient of $13,900 \mathrm{M}^{-1} \mathrm{~cm}^{-1}[16]$.
2.9. Solubility Measurement. To determine protein solubility, $200 \mathrm{mg}$ of HSPP was dispersed in $20 \mathrm{~mL}$ water. The solution was centrifuged at $10,000 \times \mathrm{g}$ for $10 \mathrm{~min}$. After an appropriate dilution, the nitrogen content of the supernatant was determined by the Kjeldahl method and the solubility was expressed as $\mathrm{g}$ soluble nitrogen $/ 100 \mathrm{~g}$ nitrogen in the sample (\% NS).

2.10. Surface Hydrophobicity Measurement. HSPP samples were dissolved in a $\mathrm{pH} 7.6$ phosphate buffer at $1 \mathrm{mg} / \mathrm{mL}$ and centrifuged at $8,000 \times \mathrm{g}$ at $4^{\circ} \mathrm{C}$ for $20 \mathrm{~min}$ [17]. An aliquots of $10 \mathrm{~mL}$ supernatant was mixed with $50 \mathrm{~mL}$ of ANS $(8.0 \mathrm{mmol} / \mathrm{L}$ in $0.05 \mathrm{~mol} / \mathrm{L}$ phosphate buffer $\mathrm{pH}$ 7.6). Fluorescence intensity (FI) was measured at $330 \mathrm{~nm}$ (excitation) and $490 \mathrm{~nm}$ (emission) using an F-4500 spectrometer (Hitachi, Ltd., Tokyo, Japan) with excitation and emission slit of $5 \mathrm{~nm}$. The hydrophobicity was calculated from the linear regression of initial slope of FI against protein concentration $(\mathrm{mg} / \mathrm{mL})$.

2.11. Water Holding Capacity (WHC). HSPP ( $1 \mathrm{~g}$ ) was weighed into a preweighed $15 \mathrm{~mL}$ centrifuge tubes [18]. For each sample, $10 \mathrm{~mL}$ of water was added and dispersed using a Vortex mixer for $2 \mathrm{~min}$. The dispersion was allowed to stand at room temperature for $30 \mathrm{~min}$, then centrifuged at $3000 \times \mathrm{g}$ for $20 \mathrm{~min}$ at room temperature. The supernatant was decanted and the centrifuge tube containing sediment was weighed. The WHC (grams of water per gram of protein) was calculated using

$$
\mathrm{WHC}=\frac{\left(W_{2}-W_{1}\right)}{W_{0}},
$$

where $W_{0}$ is the weight of the dry sample $(\mathrm{g}), W_{1}$ is the weight of the tube plus the dry sample (g) and $W_{2}$ is the weight of the tube plus the sediment (g).

2.12. Emulsion Properties Measurement. An oil-in-water (O/W) emulsion of HSPP was prepared by adding $8 \mathrm{~mL}$ of the soluble protein solution $(1 \mathrm{mg} / \mathrm{mL})$ to $2 \mathrm{~mL}$ of soybean oil and homogenizing it in a homogenizer (Fluko, Shanghai, China) at 20,000 $\mathrm{rpm}$ for $1 \mathrm{~min}$ [19]. The absorbance of the emulsion at $500 \mathrm{~nm}$ was recorded immediately $\left(A_{0}\right)$ and after $10 \mathrm{~min}$ $\left(A_{10}\right)$ using a spectrophotometer (SHJH Co. Ltd., Shanghai, China). The emulsifying activity index (EAI) and emulsion stability index (ESI) were determined using

$$
\begin{aligned}
\operatorname{EAI}\left(\mathrm{m}^{2} / \mathrm{g}\right) & =\frac{2 \times 2.303 \times A_{0} \times \mathrm{DF}}{c \times \varphi \times(1-\theta) \times 10,000} \\
\text { ESI }(\mathrm{min}) & =\frac{A_{0}}{A_{0}-A_{10}} \times 10,
\end{aligned}
$$

where $A_{0}$ and $A_{10}$ are the emulsion absorbance at 0 and $10 \mathrm{~min}$; DF is dilution factor; $\theta$ is the fraction of oil used to form the emulsion $(0.25) ; \varphi$ is the optical path $(0.01 \mathrm{~m})$; and $c$ is protein concentration in sample solution $(\mathrm{g} / \mathrm{ml})$.

2.13. Foaming Properties. Foaming properties including foaming capacity (FC) and foam stability (FS) were determined using the method of Fernández-Quintela et al. with 


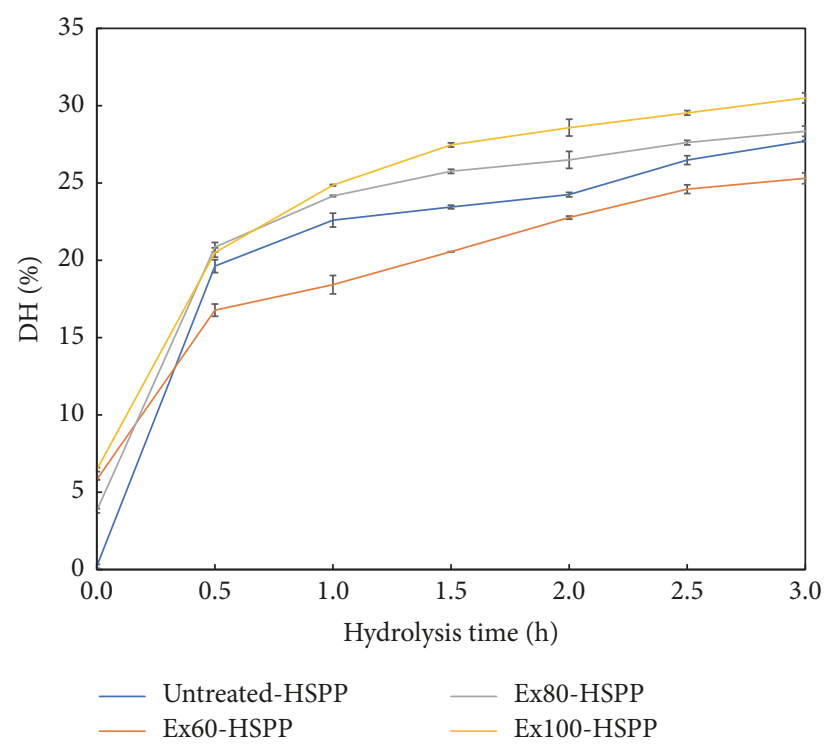

FIGURE 1: DH of hydrolyzed samples with/without extrusion.

minor modifications [20]. Aliquots $(10 \mathrm{~mL})$ of sample solutions $(1 \%, \mathrm{w} / \mathrm{v})$ at $\mathrm{pH} 7.0$ in measuring cylinder $(25 \mathrm{~mL})$ were homogenized with an FJ-200 high-speed homogenizer (Shanghai Co., China) at 10,000 rpm for 2 min. FC was calculated as the percent increase in volume of the protein dispersion upon mixing, while FS was estimated as the percentage of foam remaining after $30 \mathrm{~min}$.

2.14. Statistical Analysis. All the experiments were conducted in triplicate and results were presented as mean \pm standard deviation. Statistical analysis was performed on the obtained results using one-way analysis of variance (ANOVA) analysis and Turkey's test at $p<0.05$ using SPSS (version 17.0, SPSS Inc., Chicago, ILL, USA).

\section{Results and Discussion}

3.1. Hydrolysis Degree Analysis. The DH of HSPP is shown in Figure 1. The number of peptide bonds cleaved is quantified as DH [21]. Overall, the DH increased for all the test samples within the hydrolysis duration of $3 \mathrm{~h}$. The biggest increase was observed at the first $0.5 \mathrm{~h}$ of hydrolysis. Extrusion at $60^{\circ} \mathrm{C}$ did not increase DH compared to the nonextruded control sample. Verbeek and Van Den Berg [22] demonstrated that the stabilizing force maintaining the tertiary and quaternary structures of the proteins was weakened by a combination of increased temperature and shear within the extruder. Simmons et al. [23] also reported that small protein aggregates were formed at $75^{\circ} \mathrm{C}$ during extrusion, whereas more rigid and dense protein aggregates were formed via disulfide interactions at high extrusion temperature over $80^{\circ} \mathrm{C}$. Therefore, the significantly lowered DH of Ex60-HSPP may be due to the formed protein aggregates, which have a compact structure to impede hydrolysis. Klompong et al. [24] had similar observation that proteins with highly compacted structure were cleaved more slowly by enzymes. As temperature increased to
80 and 100, the protein aggregates tend to be broken, internal groups for enzyme hydrolysis [25]. Therefore, the formed rigid protein aggregates at the extrusion temperature of 80 and $100^{\circ} \mathrm{C}$ were further disrupted, resulting in a higher $\mathrm{DH}$.

3.2. SDS-PAGE Analysis. The nonreducing/reducing SDSPAGE of extruded and nonextruded HSPP is shown in Figure 2. As expected, proteins were hydrolyzed to small peptides after hydrolysis. The HSPP profiles were slightly different under nonreducing and reducing conditions. Under reducing conditions, disulfide bridges in proteins are disrupted, whereas such interactions are preserved under nonreducing conditions. Therefore, the existence of disulfide bonds, which were suspected to be formed after extrusion, could be identified, as shown by the bands (pointed by an arrow) between the stacking gel and the separating gel, which represented the aggregated proteins. In comparison, no clear band was observed in the nonextruded sample, which further implied that the protein aggregations were formed during extrusion procedure.

3.3. High-Performance Size Exclusion Chromatogram. The molecular weight (MW) profiles of HSPP were measured by high-performance size exclusion chromatogram with the intention of understanding the dependence of functional properties of HSPP on molecular weights. As shown in Figures 3(a)-3(d), the MW distribution can be divided into three regions: (1) region I with $\mathrm{MW}$ above $44 \mathrm{kDa}$, (2) region II with $\mathrm{MW}$ between 17 and $44 \mathrm{kDa}$, and (3) region III with MW below $17 \mathrm{kDa}$. Figure 3(a) shows that peak was minimized with the hydrolysis duration increase from 0.5 to $3.0 \mathrm{~h}$, which was attributed to the formation of peptides with small MW due to enzymatic hydrolysis. However, upon extrusion, peaks ( $a$ and b) were enlarged and the size of peak (c) decreased. The aforementioned analysis of Section 3.1 implied that the extrusion cleaved the protein structure, exposing the hidden 


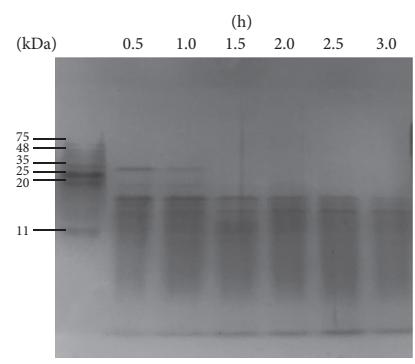

(a)

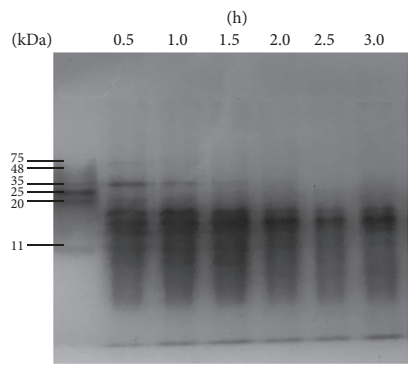

(e)

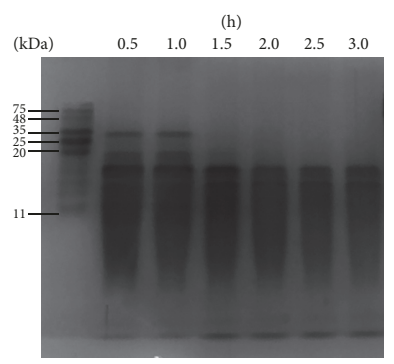

(b)

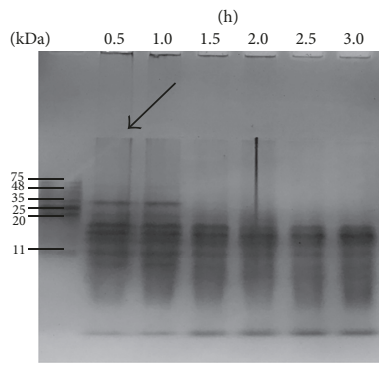

(f)

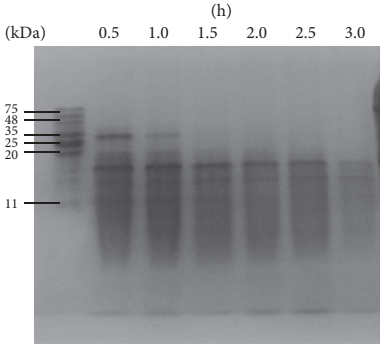

(c)

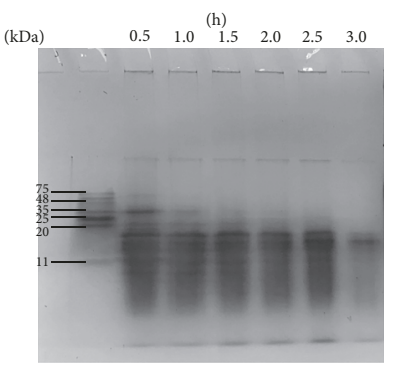

(g)

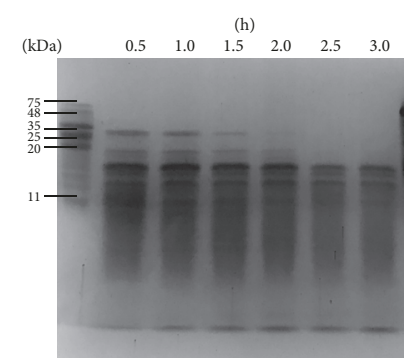

(d)

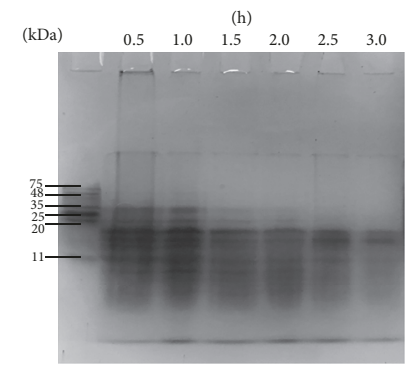

(h)

FIGURE 2: Reducing (a-d) and nonreducing (e-h) SDS-PAGE images of untreated and extruded HSPP samples: (a \& e) nonextruded, (b \& f) Ex60-HSPP, (c \& g) Ex80-HSPP, and (d \& h) Ex100-HSPP.

groups of protein to external environment. Sui et al. [13] found that the exposed anionic molecules within soy protein have emerged concomitantly with protein aggregation process. Therefore, it is assumed that the protein could form aggregates via intermolecular interactions during extrusion, resulting in the increase of MW. Similar results were reported by Nor Afizah and Rizvi [26] who suggested that protein aggregates were formed during extrusion. Although there was no significant difference in MW profile among the extruded samples, the functionalities may be significantly different.

3.4. Sulphydryl and Disulphide Bonds. Sulphydryl and disulphide bond plays an important role in the formation of relatively rigid structures and significantly influences the functional properties of proteins [27]. Figures 4 and $5(a)-5(d)$ show the total/exposed sulphydryl and disulphide bonds of HSPP. The exposed sulphydryls of HSPP were increased slightly relative to the nonextruded samples, suggesting that extrusion treatment unfolded the HSPP. It was found that hydrolysis led to a decrease of the exposed/total sulphydryl groups, with a sharp increase of disulphide bonds in HSPP relative to HSPP at $0 \mathrm{~h}$. As reported by Creusot and Gruppen [28], hydrolysis can expose sulphydryl groups and promote further interaction between these active groups to form aggregates as seen in this work. With prolonging hydrolysis time, total/exposed sulphydryl and disulphide bond contents of HSPP decreased further, which might be due a breaking of the aggregate network by enzymatic hydrolysis. The results were similar to that for peanut protein and corn glutelin reported by Zhao et al. and Zheng et al. [29, 30]. At comparable hydrolysis times, Ex100-HSPP had a higher disulfide bond content than other samples. The disulfide bond content and the surface hydrophobicity were positively correlated with the emulsification indices of the peanut proteins/peptides. This suggested that Ex100-HSPP would have a better emulsion property.

3.5. WHC. All the extruded samples showed much higher WHC than that of nonextruded sample before hydrolysis (Figures 5(e)-5(h)). A similar tendency was observed by Alonso et al. [31] that extrusion resulted in an increase in the WHC of kidney beans or peas protein. Results indicated that the hydrolysis caused significant increases in the WHC of all the samples with or without extrusion. The current results are consistent with de Oliveira et al. who found that increasing $\mathrm{DH}$ of soy protein is accompanied by an increase in WHC [32]. The increased WHC was attributed to the fact that hydrolysis with Protex preserved more hydrophilic amino acid residues and reduced the hydrophobic sites, which increased the water retention of HSPP [33].

3.6. Solubility Measurement and Surface Hydrophobicity. The protein solubility is shown in Figures 6(a)-6(d). Overall, all the extruded samples showed higher initial solubilities at the hydrolysis time of $0 \mathrm{~h}$ than that of samples without extrusion. With increasing the hydrolysis time, the solubilities of extruded and nonextruded samples increased at different rates. Similar positive correlation was also observed between the extrusion temperature and solubility, in which the Ex100HSPP showed the highest solubility. The peptides after hydrolysis of protein were able to form stronger hydrogen bonds with water and were more soluble in aqueous solutions $[34,35]$. The formation of small peptides was probably the main reason for the increased solubility. 


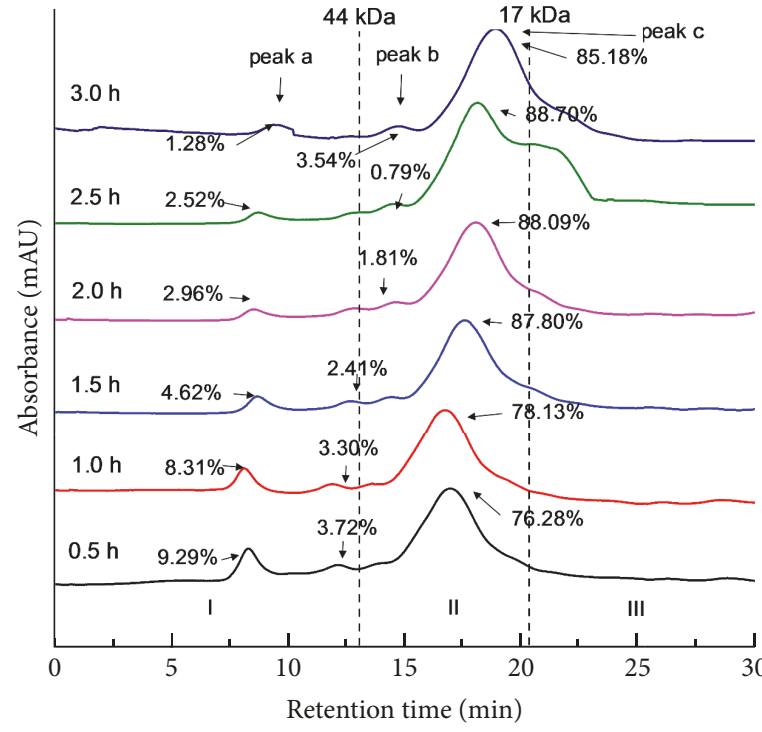

(a)

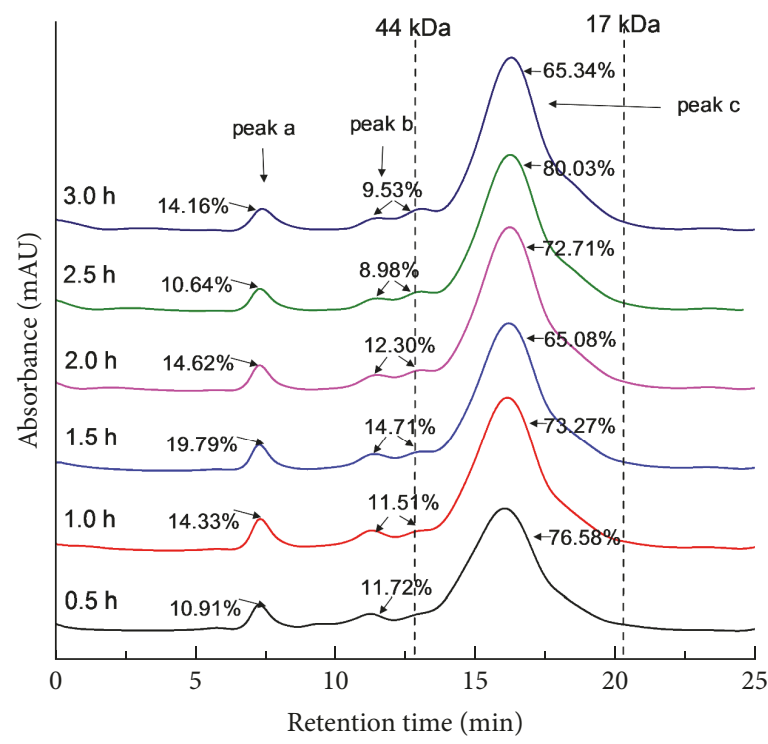

(c)

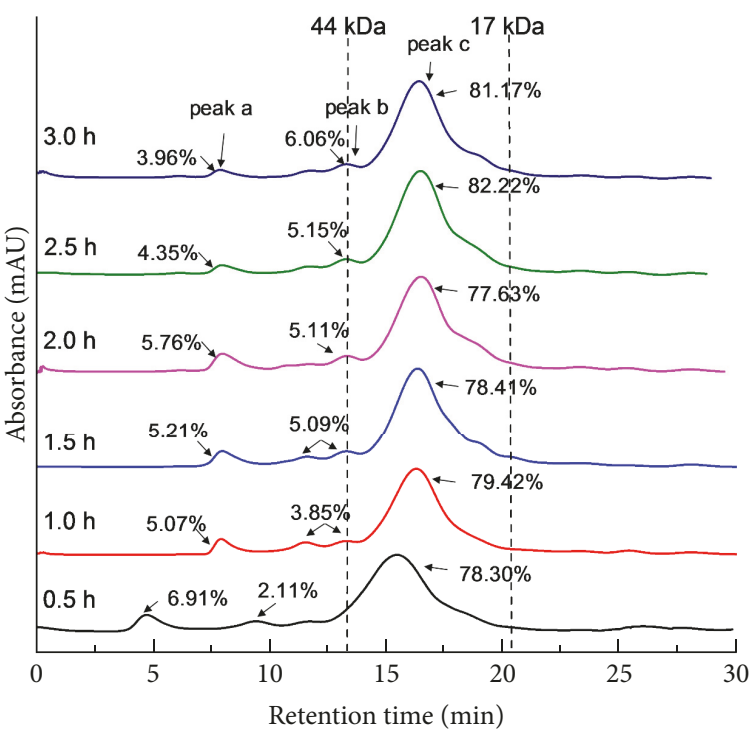

(b)

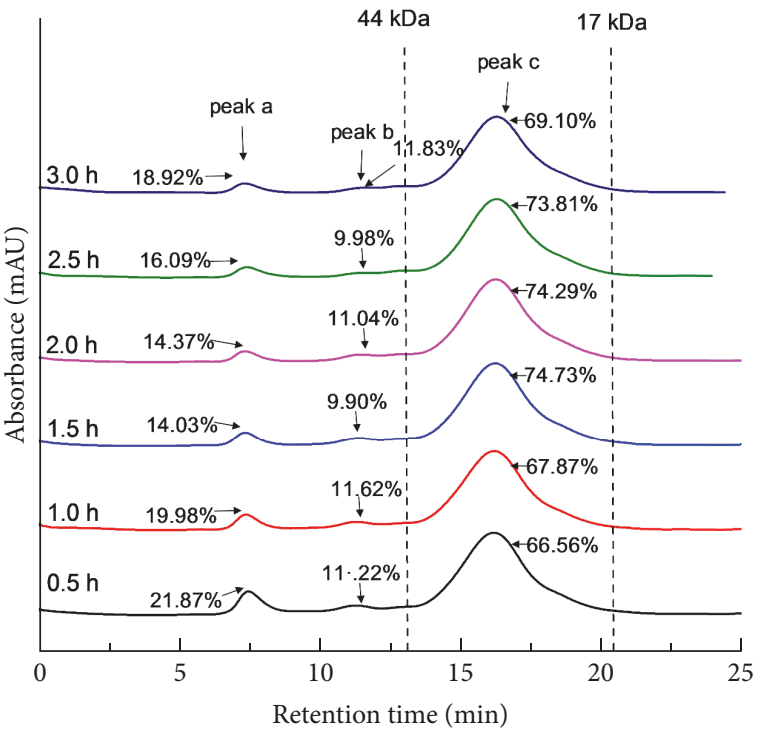

(d)

FIGURE 3: Molecular weight distributions of untreated and extruded HSPP samples: (a) nonextruded, (b) Ex60-HSPP, (c) Ex80-HSPP, and (d) Ex100-HSPP.

The surface hydrophobicity of proteins is one of the main structural characteristics used to evaluate changes in protein conformation [36]. Results indicated that the hydrolysis caused significant decreases in the hydrophobicity of all the samples with or without extrusion (Figures 6(e)-6(h)). The possible reason for the decreased hydrophobicity after hydrolysis is the increased enzymatic accessibility of HSPP, thereby causing the breakdown of hydrophobic groups during hydrolysis. Besides, the decreased hydrophobicity of HSPP might further be attributed to the formation of protein aggregates. Ryan et al. [37] found that hydrolyzed proteins were compared to nonhydrolyzed protein, in forming aggregates. It was also noted that all the extruded samples showed much lower hydrophobicity than that of nonextruded sample before hydrolysis. With an increase in the temperature of extrusion, the hydrophobicity decreased with Ex100-HSPP exhibiting the lowest initial hydrophobicity. A similar trend was also reported by Jung et al. [38] that extrusion treatment resulted in a decrease in the hydrophobicity of soy protein. This may be due to the extrusion-induced conformational changes of soy protein with a greater flexibility and more susceptible to enzymatic attack [39].

3.7. Emulsion Properties. The EAI is known to evaluate the effectiveness of proteins to preventing flocculation and coalescence in an emulsion. However, the EAI cannot descript the ability of proteins in maintaining a stable emulsion over periods, and thus the ESI was further adopted to fulfill this 


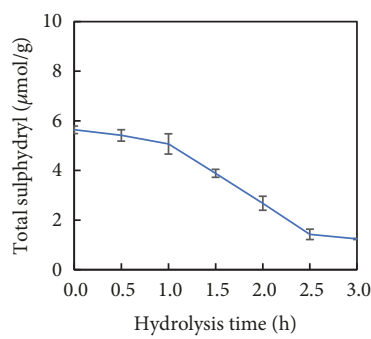

(a)

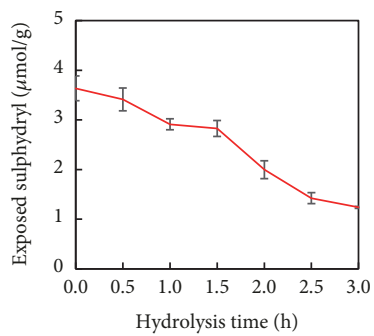

(e)

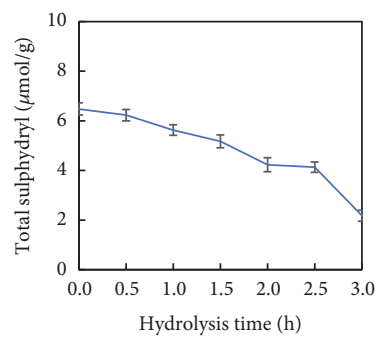

(b)

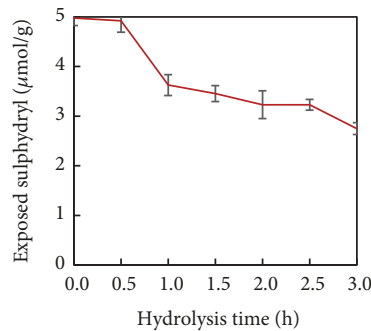

(f)

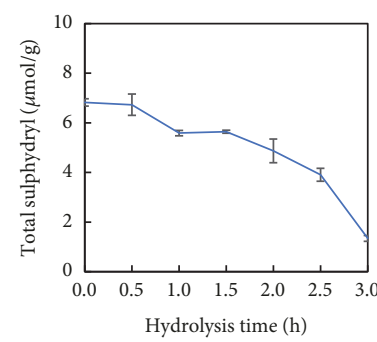

(c)

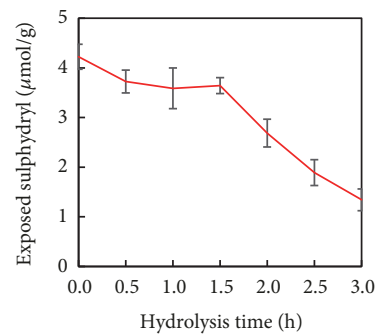

(g)

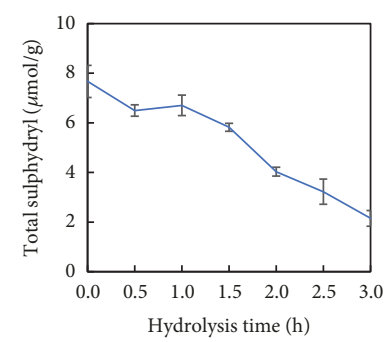

(d)

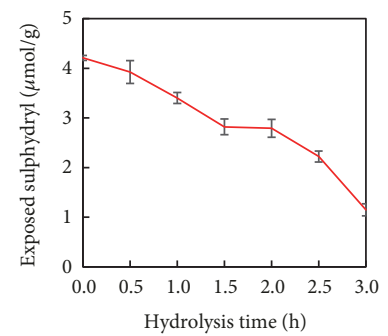

(h)

FIGURE 4: Total sulphydryl of (a) nonextruded, (b) Ex60-HSPP, (c) Ex80-HSPP, and (d) Ex100-HSPP. Exposed sulphydryl of (e) nonextruded, (f) Ex60-HSPP, (g) Ex80-HSPP, and (h) Ex100-HSPP.

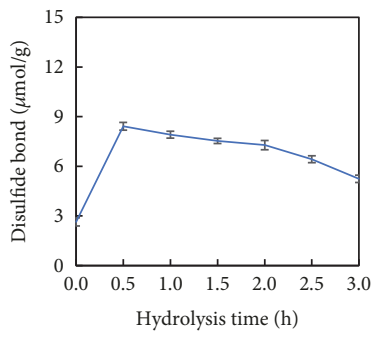

(a)

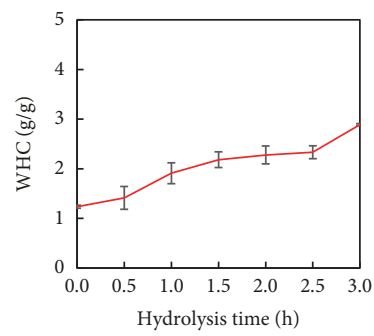

(e)

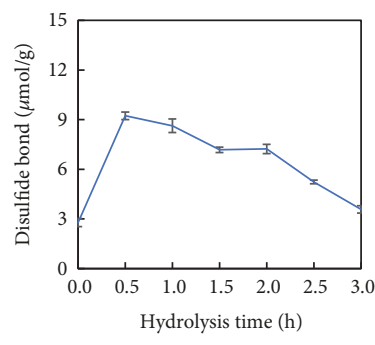

(b)

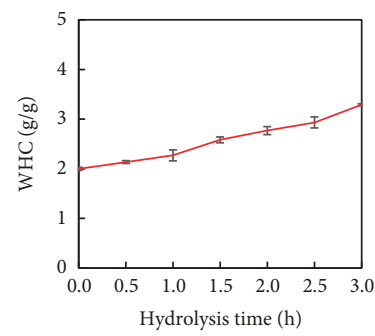

(f)

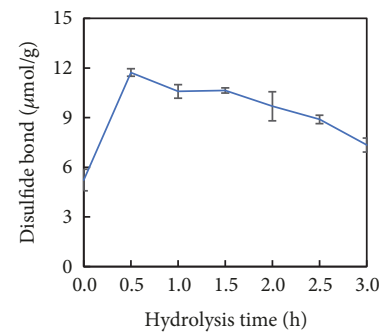

(c)

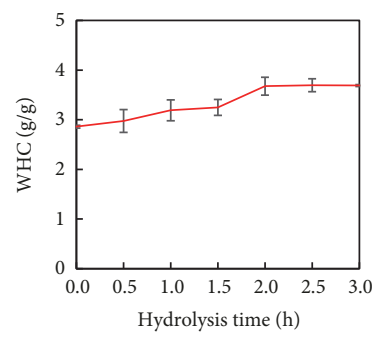

(g)

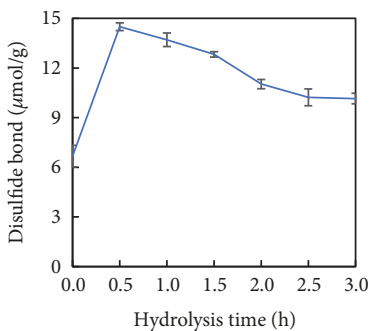

(d)

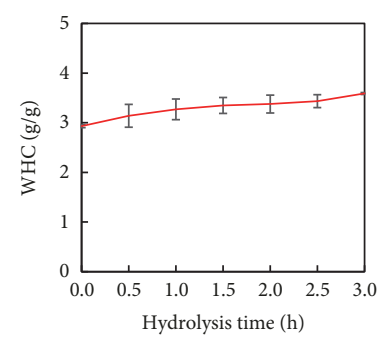

(h)

Figure 5: Disulfide bond of (a) nonextruded, (b) Ex60-HSPP, (c) Ex80-HSPP, and (d) Ex100-HSPP. WHC of (e) nonextruded, (f) Ex60-HSPP, (g) Ex80-HSPP, and (h) Ex100-HSPP.

aim. As shown in Figures 7(a)-7(d), all the extruded samples showed higher EAI level than nonextruded sample. The increased EAI of Ex60-HSPP was attributed to the extrusion process, which made proteins more sensitive to enzymatic hydrolysis. Interestingly, the EAI did not increase continuously with an increase in the extrusion temperature to $80^{\circ} \mathrm{C}$. The thermal denaturation temperatures of $\beta$-conglycinin and glycinin were reported to be $65-75$ and $85-95^{\circ} \mathrm{C}$ [40]. Therefore, the reduced EAI of Ex80-HSPP was suspected to be the thermal-induced denaturation of glycinin. The EAI of Ex100-HSPP was much higher than all others, although both $\beta$-conglycinin and glycinin were thermally denatured at $100^{\circ} \mathrm{C}$. This observation may seem to conflict with the above conclusion; however the higher solubility of Ex100HSPP could explain the problem, since proteins with high solubilities can rapidly diffuse and adsorb at the interface of droplets to form a stable emulsion [40]. It reached a descriptive rather than prescriptive conclusion that the thermalinduced decrease in EAI of HSPP at $100^{\circ} \mathrm{C}$ was compensated by its high solubility. However, the EAI sharply decreased for 


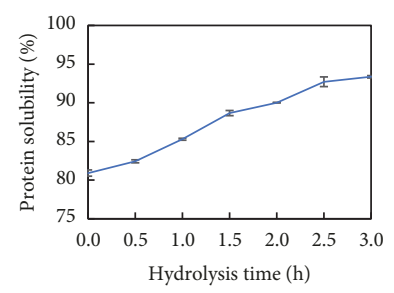

(a)

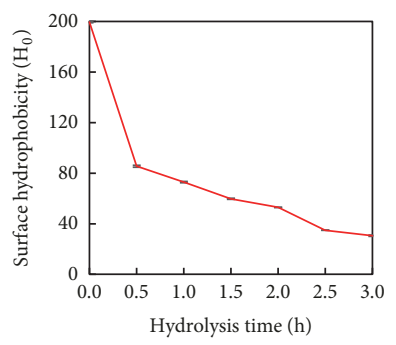

(e)

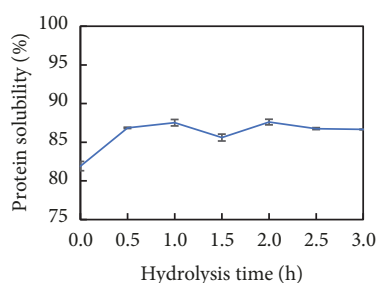

(b)

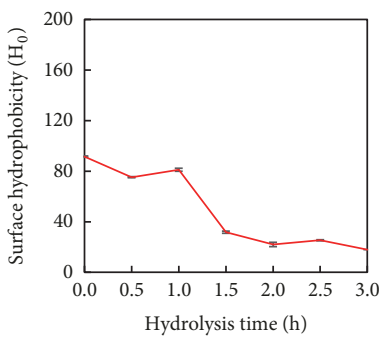

(f)

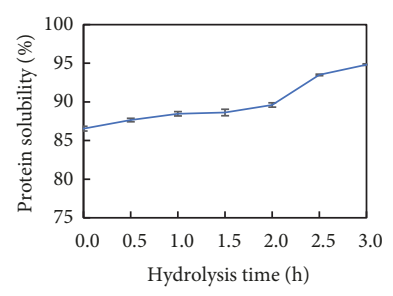

(c)

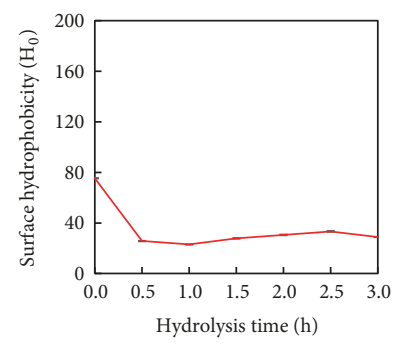

(g)

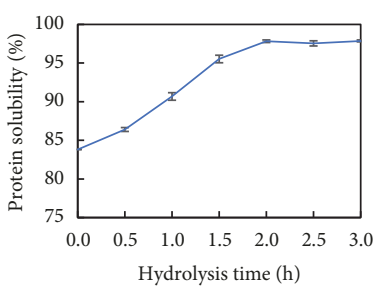

(d)

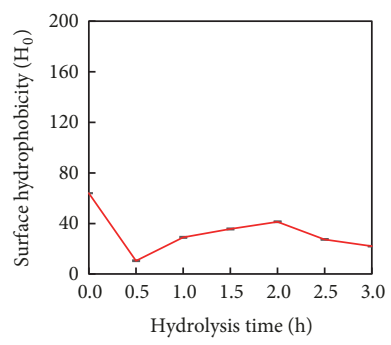

(h)

Figure 6: Protein solubility behavior of (a) nonextruded, (b) Ex60-HSPP, (c) Ex80-HSPP, and (d) Ex100-HSPP. Surface hydrophobicity behavior of (e) nonextruded, (f) Ex60-HSPP, (g) Ex80-HSPP, and (h) Ex100-HSPP.

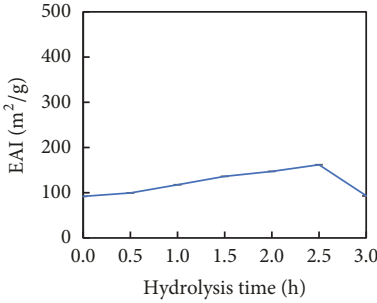

(a)

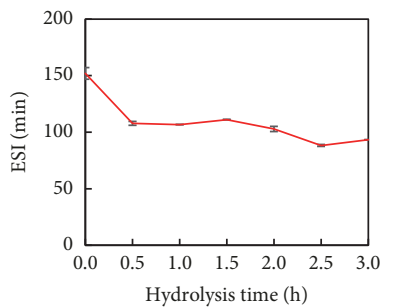

(e)

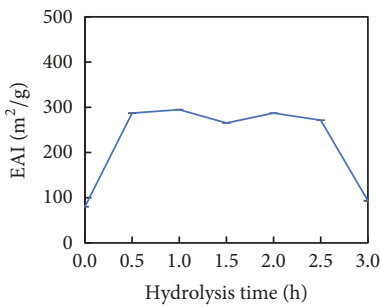

(b)

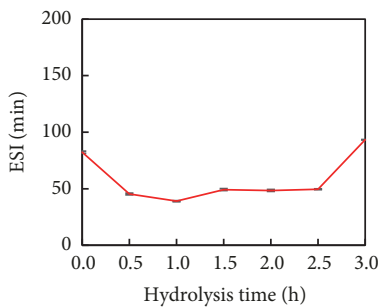

(f)

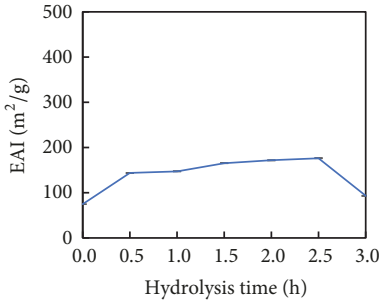

(c)

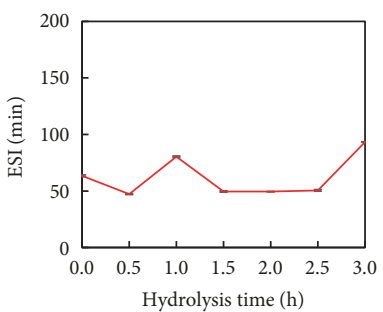

(g)

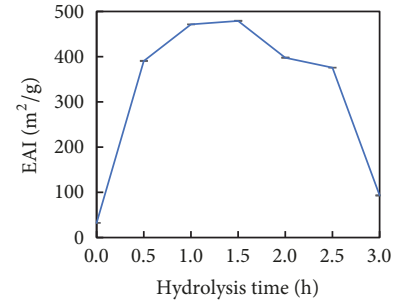

(d)

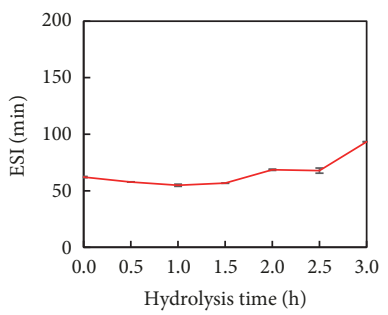

(h)

Figure 7: EAI and ESI analysis of (a \& e) nonextruded, (b \& f) Ex60-HSPP, (c \& g) Ex80-HSPP, and (d \& h) Ex100-HSPP.

all samples after $3 \mathrm{~h}$ of hydrolysis. Kristinsson and Rasco [41] reported a decreased EAI after enzymatic hydrolysis of $2 \mathrm{~h}$, which may be due to the decreased protein peptide chain length. Mokni Ghribi et al. [42] similarly found that the hydrolysis process reduced the ability of smaller peptides to interact at the interface of droplets, causing the decreased EAI. Therefore, the decreased EAI after hydrolysis of $3 \mathrm{~h}$ was concluded to be due to the excessive hydrolysis.

As shown in Figures 7(e)-7(h), all the extruded samples showed larger decrease in ESI than the nonextruded sample. This indicated that the extruded proteins had weaker abilities to maintain a stable emulsion during storage, regardless their great effectiveness in forming emulsions, which was reflected by their higher EAI. Smaller peptides are known for their lower efficiency in stabilizing emulsions because they may not readily agglomerate to produce a fat globule membrane due to the charge repulsions and surface hydrophobicity [43, 44]. Thereafter, the smaller peptides formed during extrusion were considered as the major reason for the decreased ESI.

3.8. Foaming Properties. As DH increased, the foaming capacity of HSPP increased $(0-2.0 \mathrm{~h})$ then decreased $(2.0-3.0 \mathrm{~h})$ as shown in Figures $8(\mathrm{a})-8(\mathrm{~d})$. This could be due to the production of amphiphilic peptides after hydrolysis. Their reduced molecular weight will make them more flexible, forming a stable interfacial layer and increasing the rate of diffusion to 


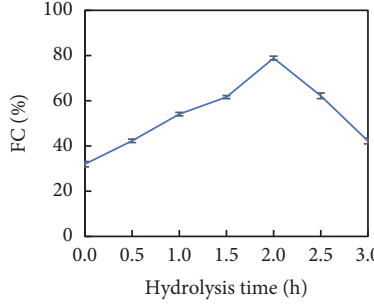

(a)

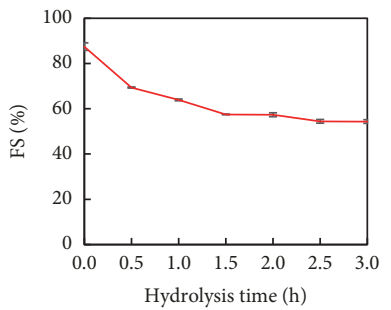

(e)

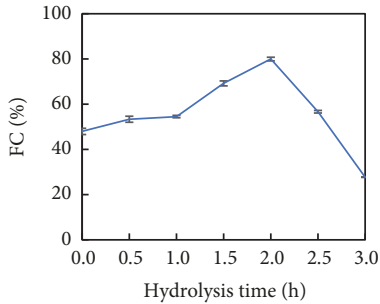

(b)

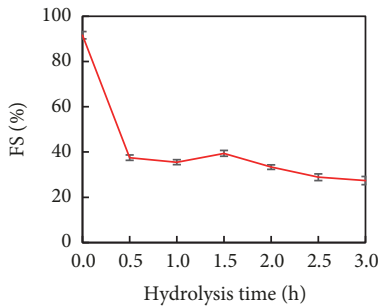

(f)

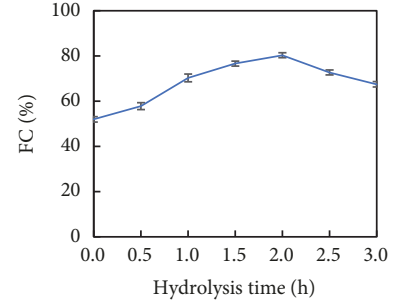

(c)

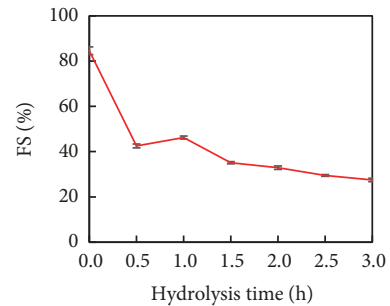

(g)

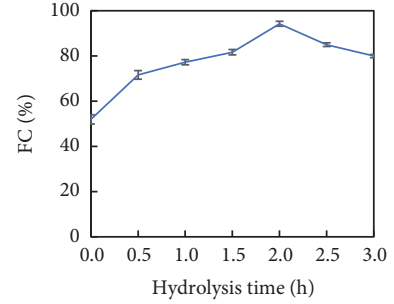

(d)

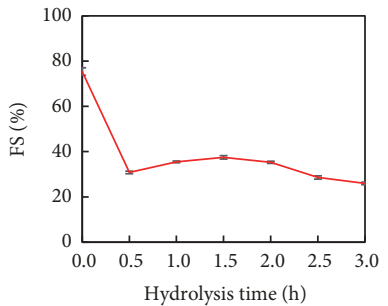

(h)

Figure 8: FC and FS analysis of (a \& e) nonextruded, (b \& f) Ex60-HSPP, (c \& g) Ex80-HSPP, and (d \& h) Ex100-HSPP.

the interface, improving the foamability properties. The large peptides and aggregates may have an inhibitory effect on the foaming properties by steric hindrance at the interface of the foam [45]. The higher FC of the Ex100-HSPP is consistent with the observed higher solubility and suggested that greater interactions with the aqueous phase enhance the ability of the protein molecules to encapsulate air particles. Interactions with the hydrophilic aqueous phase will enhance protein unfolding and hence result in better foam forming ability [46].

As shown in Figures 8(e)-8(h), enzymatic hydrolysis led to significant decreases in FS. Thus, the decreased chain length of peptides as a result of enzymatic hydrolysis may mainly account for the decrease in FS as with emulsion stability. The result are consistent with Wouters et al. [47]. The higher FS properties of nonextruded HSPP may be attributed to higher surface hydrophobicity, which enhance strong protein-protein interactions (as evident in Figure 5) and formation of a strong interfacial membrane at the air-water interface.

\section{Conclusion}

The hybrid extrusion-hydrolysis approach exhibited significant influence on the conformational and functional properties of soybean protein. Results showed that proteins formed more compacted aggregates at extrusion temperatures of $60^{\circ} \mathrm{C}$ than that formed at 80 and $100^{\circ} \mathrm{C}$, which was indicated by the $\mathrm{DH}$ analysis. During extrusion, proteins might have interacted via disulfide bonds, forming aggregates with increased MW. With the introduction of enzymatic hydrolysis, the WHC and solubility of proteins increased and the hydrophobicity of proteins decreased. Extruded proteins showed higher EAI and FC than that of nonextruded proteins. However, excessive enzymatic hydrolysis reduced the EAI and FS due to the decreased protein peptide chain length.

\section{Data Availability}

The data used to support the findings of this study are available from the corresponding author upon request.

\section{Conflicts of Interest}

The authors declare that there are no conflicts of interest regarding the publication of this paper.

\section{Authors' Contributions}

The first and second authors contributed equally to this work.

\section{Acknowledgments}

This work was supported by the National Key Research and Development Program of China (2016YFD0401402), the National Natural Science Foundation of China (nos. 3143000560, 31301501, and 31571876), and Fok Ying Tung Education Foundation (no. 151032).

\section{References}

[1] W. Shurtleff and A. Aoyagi, History of Modern Soy Protein Ingredients-Isolates, Concentrates, and Textured Soy Protein Products (1911-2016): Extensively Annotated Bibliography and Sourcebook, Soyinfo Center, 2016.

[2] W. J. Wolf, J. C. Cowan, and H. Wolff, "Soybeans as a food source," Critical Reviews in Food Science and Nutrition, vol. 2, no. 1, pp. 81-158, 1971.

[3] M. S. Alam, J. Kaur, H. Khaira, and K. Gupta, "Extrusion and extruded products: changes in quality attributes as affected by extrusion process parameters: a review," Critical Reviews in Food Science and Nutrition, vol. 56, no. 3, pp. 445-475, 2016. 
[4] J. Jiang, Y. L. Xiong, and J. Chen, "PH shifting alters solubility characteristics and thermal stability of soy protein isolate and its globulin fractions in different $\mathrm{pH}$, salt concentration, and temperature conditions," Journal of Agricultural and Food Chemistry, vol. 58, no. 13, pp. 8035-8042, 2010.

[5] H. R. Sharif, P. A. Williams, M. K. Sharif et al., "Current progress in the utilization of native and modified legume proteins as emulsifiers and encapsulants-a review," Food Hydrocolloids, vol. 76, pp. 1-16, 2018.

[6] A. Clemente, "Enzymatic protein hydrolysates in human nutrition," Trends in Food Science \& Technology, vol. 11, no. 7, pp. 254262, 2001.

[7] L. Chen, J. Chen, J. Ren, and M. Zhao, "Modifications of soy protein isolates using combined extrusion pre-treatment and controlled enzymatic hydrolysis for improved emulsifying properties," Food Hydrocolloids, vol. 25, no. 5, pp. 887-897, 2011.

[8] B. P. Lamsal, C. Reitmeier, P. A. Murphy, and L. A. Johnson, "Enzymatic hydrolysis of extruded-expelled soy flour and resulting functional properties," Journal of the American Oil Chemists' Society, vol. 83, no. 8, pp. 731-737, 2006.

[9] K. Surowka, D. Zmudzinski, and J. Surowka, "Enzymic modification of extruded soy protein concentrates as a method of obtaining new functional food components," Trends in Food Science \& Technology, vol. 15, no. 3, pp. 153-160, 2004.

[10] Y. Li, Y. Zhang, M. Wang, L. Jiang, and X. Sui, "Simplex-centroid mixture design applied to the aqueous enzymatic extraction of fatty acid-balanced oil from mixed seeds," Journal of the American Oil Chemists' Society, vol. 90, no. 3, pp. 349-357, 2013.

[11] P. M. Nielsen, D. Petersen, and C. Dambmann, "Improved method for determining food protein degree of hydrolysis," Journal of Food Science, vol. 66, no. 5, pp. 642-646, 2001.

[12] L. Z. Jiang, J. Wang, Y. Li et al., "Effects of ultrasound on the structure and physical properties of black bean protein isolates," Food Research International, vol. 62, pp. 595-601, 2014.

[13] X. Sui, S. Bi, B. Qi et al., "Impact of ultrasonic treatment on an emulsion system stabilized with soybean protein isolate and lecithin: Its emulsifying property and emulsion stability," Food Hydrocolloids, vol. 63, pp. 727-734, 2017.

[14] M.-H. Morel, P. Dehlon, J. C. Autran, J. P. Leygue, and C. Barlhelgouach, "Effects of temperature, sonication time, and power settings on size distribution and extractability of total wheat flour proteins as determined by size-exclusion highperformance liquid chromatography," Cereal Chemistry, vol. 77, no. 5, pp. 685-691, 2000.

[15] T. Beveridge, S. J. Toma, and S. Nakai, "Determination of SHand SS-groups in some food proteins using Ellman's reagent," Journal of Food Science, vol. 39, pp. 49-51, 1974.

[16] T. W. Thannhauser, Y. Konishi, and H. A. Scheraga, "Sensitive quantitative analysis of disulfide bonds in polypeptides and proteins," Analytical Biochemistry, vol. 138, no. 1, pp. 181-188, 1984.

[17] A. Kato and S. Nakai, "Hydrophobicity determined by a fluorescence probe method and its correlation with surface properties of proteins.," Biochimica et Biophysica Acta, vol. 624, no. 1, pp. 13-20, 1980.

[18] M. Ahmedna, W. Prinyawiwatkul, and R. M. Rao, "Solubilized wheat protein isolate: Functional properties and potential food applications," Journal of Agricultural and Food Chemistry, vol. 47, no. 4, pp. $1340-1345,1999$.

[19] K. N. Pearce and J. E. Kinsella, "Emulsifying properties of proteins: evaluation of a turbidimetric technique," Journal of
Agricultural and Food Chemistry, vol. 26, no. 3, pp. 716-723, 1978.

[20] A. Fernández-Quintela, M. T. Macarulla, A. S. Del Barrio, and J. A. Martínez, "Composition and functional properties of protein isolates obtained from commercial legumes grown in northern Spain," Plant Foods for Human Nutrition, vol. 51, no. 4, pp. 331342, 1997.

[21] E. Rajarathnam, A. B. Nongonierma, D. O’Sullivan, C. Flynn, and R. J. FitzGerald, "Impact of enzyme preparation and degree of hydrolysis on peptide profile and nitrogen solubility of sodium caseinate hydrolysates," International Journal of Food Science \& Technology, vol. 51, no. 9, pp. 2123-2131, 2016.

[22] C. J. R. Verbeek and L. E. Van Den Berg, "Extrusion processing and properties of protein-based thermoplastics," Macromolecular Materials and Engineering, vol. 295, no. 1, pp. 10-21, 2010.

[23] M. J. H. Simmons, P. Jayaraman, and P. J. Fryer, “The effect of temperature and shear rate upon the aggregation of whey protein and its implications for milk fouling," Journal of Food Engineering, vol. 79, no. 2, pp. 517-528, 2007.

[24] V. Klompong, S. Benjakul, D. Kantachote, and F. Shahidi, "Antioxidative activity and functional properties of protein hydrolysate of yellow stripe trevally (Selaroides leptolepis) as influenced by the degree of hydrolysis and enzyme type," Food Chemistry, vol. 102, no. 4, pp. 1317-1327, 2007.

[25] C. I. Onwulata, R. P. Konstance, P. H. Cooke, and H. M. Farrell Jr., "Functionality of extrusion-texturized whey proteins," Journal of Dairy Science, vol. 86, no. 11, pp. 3775-3782, 2003.

[26] M. Nor Afizah and S. S. H. Rizvi, "Functional properties of whey protein concentrate texturized at acidic $\mathrm{pH}$ : effect of extrusion temperature," LWT - Food Science and Technology, vol. 57, no. 1, pp. 290-298, 2014.

[27] K. Shimada and J. Claude Cheftel, "Texture characteristics, protein solubility, and sulfhydryl group/disulfide bond contents of heat-induced gels of whey protein isolate," Journal of Agricultural and Food Chemistry, vol. 36, no. 5, pp. 1018-1025, 1988.

[28] N. Creusot and H. Gruppen, "Hydrolysis of whey protein isolate with Bacillus licheniformis protease: Fractionation and identification of aggregating peptides," Journal of Agricultural and Food Chemistry, vol. 55, no. 22, pp. 9241-9250, 2007.

[29] G. Zhao, Y. Liu, M. Zhao, J. Ren, and B. Yang, "Enzymatic hydrolysis and their effects on conformational and functional properties of peanut protein isolate," Food Chemistry, vol. 127, no. 4, pp. 1438-1443, 2011.

[30] X.-Q. Zheng, J.-T. Wang, X.-L. Liu et al., "Effect of hydrolysis time on the physicochemical and functional properties of corn glutelin by Protamex hydrolysis," Food Chemistry, vol. 172, pp. 407-415, 2015.

[31] R. Alonso, E. Orúe, M. J. Zabalza, G. Grant, and F. Marzo, "Effect of extrusion cooking on structure and functional properties of pea and kidney bean proteins," Journal of the Science of Food and Agriculture, vol. 80, no. 3, pp. 397-403, 2000.

[32] C. F. de Oliveira, A. P. F. Corrêa, D. Coletto, D. J. Daroit, F. Cladera-Olivera, and A. Brandelli, "Soy protein hydrolysis with microbial protease to improve antioxidant and functional properties," Journal of Food Science and Technology, vol. 52, no. 5, pp. 2668-2678, 2015.

[33] H. G. Kristinsson and B. A. Rasco, "Biochemical and functional properties of Atlantic salmon (Salmo salar) muscle proteins hydrolyzed with various alkaline proteases," Journal of Agricultural and Food Chemistry, vol. 48, no. 3, pp. 657-666, 2000.

[34] G. A. Gbogouri, M. Linder, J. Fanni, and M. Parmentier, "Influence of hydrolysis degree on the functional properties of salmon 
byproducts hydrolysates," Journal of Food Science, vol. 69, no. 8, pp. C615-C622, 2004.

[35] O. L. Tavano, "Protein hydrolysis using proteases: An important tool for food biotechnology," Journal of Molecular Catalysis B: Enzymatic, vol. 90, pp. 1-11, 2013.

[36] Q.-T. Zhang, Z.-C. Tu, H. Xiao et al., "Influence of ultrasonic treatment on the structure and emulsifying properties of peanut protein isolate," Food and Bioproducts Processing, vol. 92, no. 1, pp. 30-37, 2014.

[37] K. N. Ryan, B. Vardhanabhuti, D. P. Jaramillo, J. H. van Zanten, J. N. Coupland, and E. A. Foegeding, "Stability and mechanism of whey protein soluble aggregates thermally treated with salts," Food Hydrocolloids, vol. 27, no. 2, pp. 411-420, 2012.

[38] S. Jung, A. Mahfuz, and D. Maurer, "Structure, protein interactions and in vitro protease accessibility of extruded and pressurized full-fat soybean flakes," Journal of the American Oil Chemists' Society, vol. 86, no. 5, pp. 475-483, 2009.

[39] K. Surówka, D. Zmudziński, M. Fik, R. Macura, and W. Łasocha, "New protein preparations from soy flour obtained by limited enzymic hydrolysis of extrudates," Innovative Food Science and Emerging Technologies, vol. 5, no. 2, pp. 225-234, 2004.

[40] A. C. Karaca, N. Low, and M. Nickerson, "Emulsifying properties of chickpea, faba bean, lentil and pea proteins produced by isoelectric precipitation and salt extraction," Food Research International, vol. 44, no. 9, pp. 2742-2750, 2011.

[41] H. G. Kristinsson and B. A. Rasco, "Fish protein hydrolysates: production, biochemical, and functional properties," Critical Reviews in Food Science and Nutrition, vol. 40, no. 1, pp. 43-81, 2000.

[42] A. Mokni Ghribi, I. Maklouf Gafsi, A. Sila et al., "Effects of enzymatic hydrolysis on conformational and functional properties of chickpea protein isolate," Food Chemistry, vol. 187, pp. 322-330, 2015.

[43] L. Chen, J. Chen, J. Ren, and M. Zhao, "Effects of ultrasound pretreatment on the enzymatic hydrolysis of soy protein isolates and on the emulsifying properties of hydrolysates," Journal of Agricultural and Food Chemistry, vol. 59, no. 6, pp. 2600-2609, 2011.

[44] A. Koh, G. Gillies, J. Gore, and B. R. Saunders, "Flocculation and coalescence of oil-in-water poly(dimethylsiloxane) emulsions," Journal of Colloid and Interface Science, vol. 227, no. 2, pp. 390397, 2000.

[45] R. Ben Slama-Ben Salem, I. Bkhairia, O. Abdelhedi, and M. Nasri, "Octopus vulgaris protein hydrolysates: characterization, antioxidant and functional properties," Journal of Food Science and Technology, vol. 54, no. 6, pp. 1442-1454, 2017.

[46] M. Sunde, C. L. L. Pham, and A. H. Kwan, "Molecular characteristics and biological functions of surface-active and surfactant proteins," Annual Review of Biochemistry, vol. 86, pp. 585-608, 2017.

[47] A. G. B. Wouters, E. Fierens, I. Rombouts, K. Brijs, I. J. Joye, and J. A. Delcour, "Exploring the Relationship between Structural and Air-Water Interfacial Properties of Wheat (Triticum aestivum L.) Gluten Hydrolysates in a Food System Relevant $\mathrm{pH}$ Range," Journal of Agricultural and Food Chemistry, vol. 65, no. 6, pp. 1263-1271, 2017. 

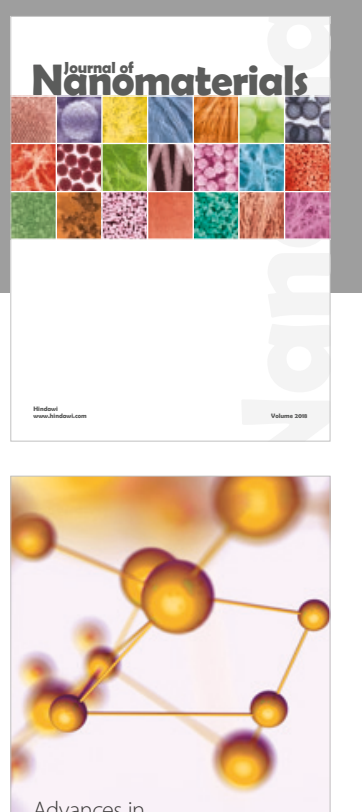

Physical Chemistry
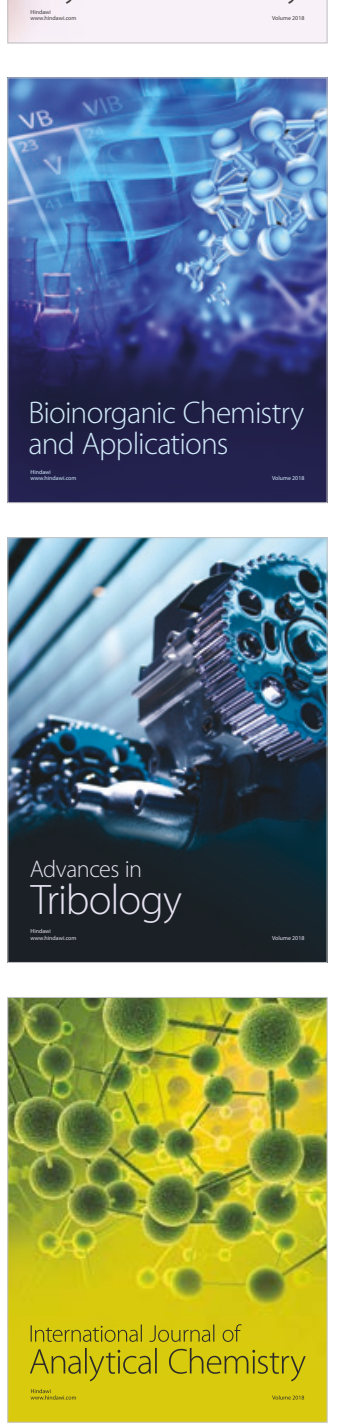

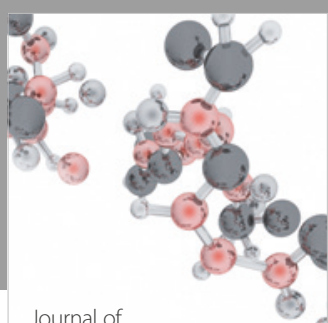

Analytical Methods

in Chemistry

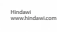

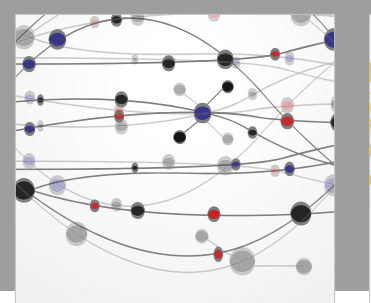

The Scientific World Journal

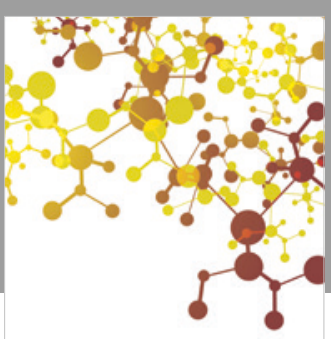

Journal of

Applied Chemistry
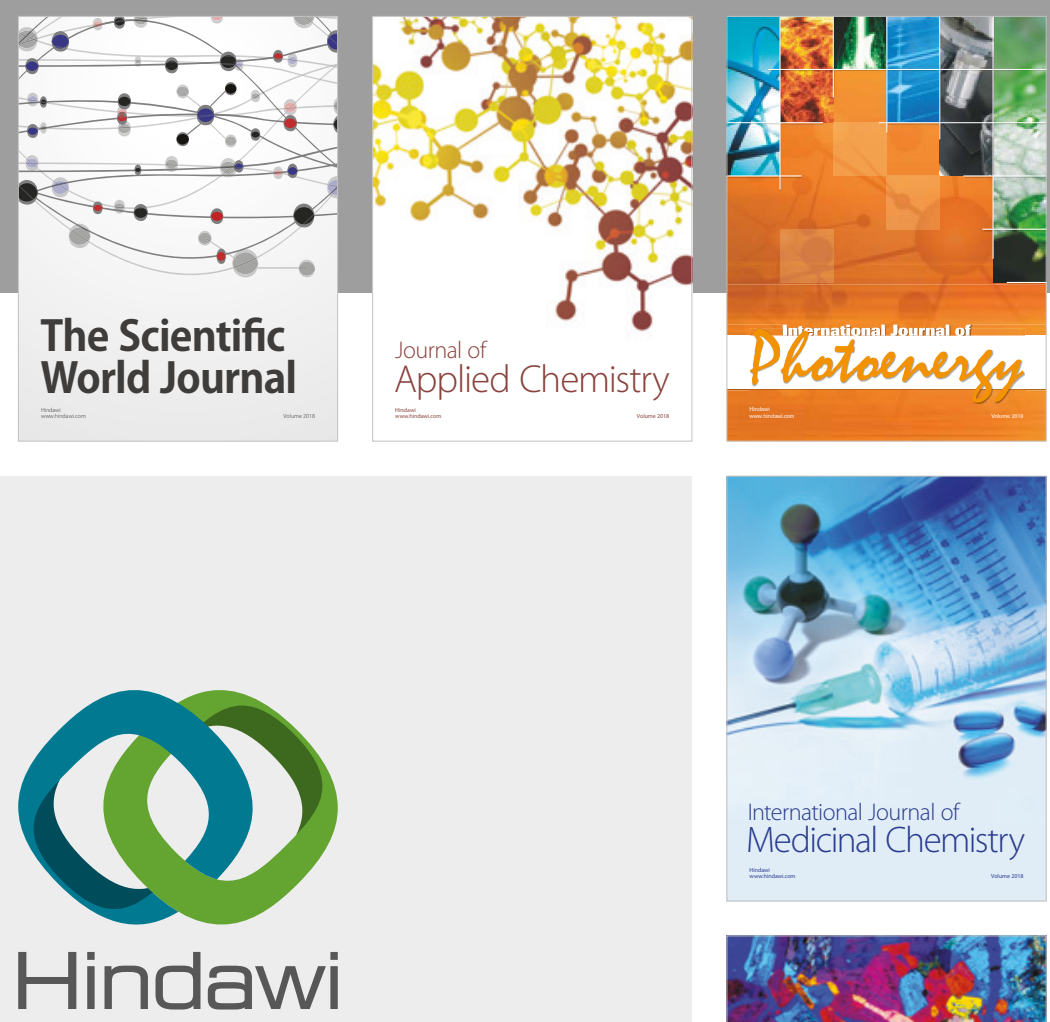

Submit your manuscripts at

www.hindawi.com
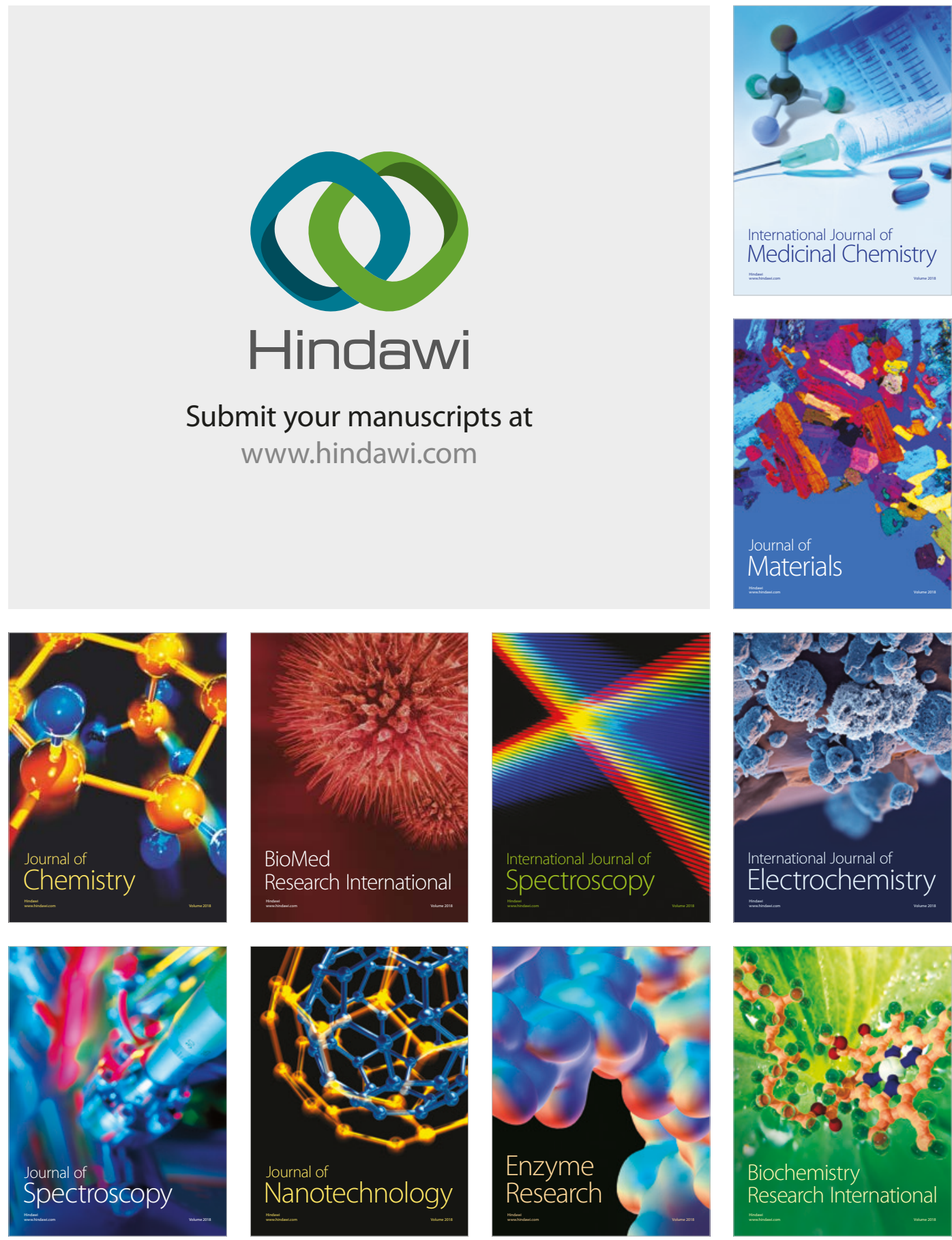
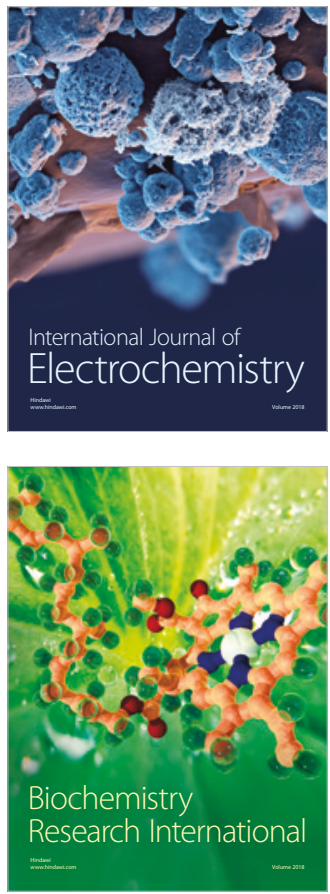